\title{
Evaluation of Clinical, Biochemical, and Genetic Characteristics and Long-Term Follow up of Adult Patients with Non-Neuronopathic Gaucher's Disease
}

Nöronopatik Olmayan Gaucher Hastahı̆ı olan Erişkin Hastaların Klinik, Biyokimyasal ve Genetik Özelliklerinin Değerlendirilmesi ve Uzun Süreli Takibi

${ }^{1}$ Gonca Kılıç Yıldırım, ${ }^{2}$ Neslihan Andıç

${ }^{1}$ Eskisehir Osmangazi University Faculty of Medicine, Department of Paediatrics, Division of Child Nutrition and

Metabolism, Eskisehir, Turkey

${ }^{2}$ Eskisehir Osmangazi University Faculty of Medicine, Department of HematologyOncology, Eskisehir, Turkey

\section{Abstract}

Gaucher disease (GD) is a lysosomal storage disorder caused by deficiencies of the $\beta$-glucocerebrosidase enzyme due to mutations in the GBA (glucosidase beta acid) gene, and that leads to the abnormal accumulation of glucocerebroside in lysosomal macrophages. The aim of the present study is to increase awareness of GD by discussing findings related to adults. Here, we report on the clinical features, laboratory parameters, and molecular characteristics of 18 adult patients with non-neuronopathic GD, as well as the hematologic, skeletal, and visceral responses of 15 patients who underwent enzyme replacement therapy (ERT). The age of symptom onset was between 1.6 and 63 years, and there was a delay of mean 3.56 years (0-21 years) from the time of symptom onset to confirmation of diagnosis. Despite the fact that three of our patients had a pathology report supporting GD, they were unaware of their diagnosis, and their care was delayed for years as they were not recommended to see a specialist, or were unable to find one. Hepatosplenomegaly, anemia, and thrombocytopenia were present in most of the patients, and in nine of the 15 patients $(60 \%)$ with thrombocytopenia, the condition was moderate. Osteopenia was present in $75 \%$ and avascular necrosis in $16.6 \%$. The most common mutant allele detected in this cohort was N409S (previously N370S), followed by L483P (previously L444P), and S405T mutations were reported. Of the total,15 patients were able to undergo ERT, which significantly improved their hematologic parameters, especially in the first year, and decreased the sizes of the liver and spleen. Physicians, particularly those working in hematology and internal medicine, should suspect GD in any adult patient with bone pain and unexplained hematologic dysfunction, especially if organomegaly is present. A multidisciplinary team approach is needed for the management of multisystemic symptoms.

Keywords: Adult, hepatosplenomegaly, hemoglobin concentration, non-neuronopathic Gaucher disease, platelet count, ferritin
Correspondence:

Gonca KILIÇ YILDIRIM

Eskisehir Osmangazi University

Faculty of Medicine, Department of Paediatrics, Division of Child

Nutrition and Metabolism, Eskisehir, Turkey

e-mail: gyildirim@ogu.edu.tr

\section{Özet}

Gaucher hastalığı (GH), GBA (glukozidaz beta asit) genindeki mutasyonlar sonucu $\beta$-glukoserebrosidaz enzim eksikliğinin neden olduğu ve makrofajlarda anormal glukoserebrosid birikimine yol açan bir lizozomal depolama bozukluğudur. Bu çalışmanın amacı, erişkin hastalar ile ilgili bulguları tartışarak GH'nin farkındalığını artırmaktır. Çalışmamızda, nöronopatik olmayan Gaucher hastalığı olan 18 erişkin hastanın klinik özellikleri, laboratuar parametreleri ve moleküler özelliklerinin yanı sıra enzim replasman tedavisi (ERT) gören 15 hastanın hematolojik, iskelet ve viseral organ yanıtlarını bildiriyoruz. Semptomların başlangıç yaşı 1,6 ile 63 yıl arasındaydı ve semptom başlangıcından tanının doğrulanmasına kadar ortalama 3,56 yıl (0-21 yıl) gecikme saptandı. Üç hastamız GH'yi destekleyen bir patoloji raporları olmasına rağmen tanılarının farkında değillerdi ve bir uzmana görünmeleri önerilmediği veya bulamadıkları için bakımları yıllarca ertelendiği görüldü. Hastaların çoğunda hepatosplenomegali, anemi ve trombositopeni mevcuttu ve trombositopenili 15 hastanın dokuzunda (\%60) orta düzeydeydi. Osteopeni \%75 ve avasküler nekroz \% 16.6 oranında mevcuttu. Bu kohortta saptanan en yaygın mutant allel, N409S (önceden N370S) idi, ardından L483P (önceden L444P) ve S405T mutasyonları rapor edildi. Toplam 15 hastaya ERT uygulanabildi, özellikle ilk yılda hematolojik parametrelerini önemli ölçüde iyileștirirken, karaciğer ve dalak boyutlarını anlamlı olarak düșürdüğü saptandı. Hekimler, özellikle hematoloji ve dahili tıp alanında çalışanlar, kemik ağrısı ve açıklanamayan hematolojik disfonksiyonu olan herhangi bir erişkin hastada, özellikle organomegali varsa GH'den şüphelenmelidir. Multisistemik semptomların yönetimi için multidisipliner bir ekip yaklaşımına ihtiyaç vardır.

Anahtar Kelimeler: Erişkin, hepatosplenomegali, hemoglobin konsantrasyonu, nöronopatik olmayan Gaucher hastalığı, trombosit sayısı, ferritin 


\section{Introduction}

Gaucher disease (GD) is an autosomal recessive disorder caused by a deficiency of the $\beta$-glucocerebrosidase enzyme due to mutations in the GBA (OMIM: 606463) gene (1). Clinically, three major forms of GD have been identified, based on their characteristic features, age of onset and central nervous system involvement (2). Among these, nonneuronopathic (Type 1) GD is the most common form, and can occur at any age, but is often diagnosed in adulthood, and the central nervous system is usually unaffected. The incidence is $1 / 40,000-60,000$ births in the general population, but can reach $1 / 850$ births in the Ashkenazi Jewish population (3). The main clinical signs and symptoms include painless splenomegaly, hepatomegaly, anemia, thrombocytopenia and chronic fatigue due to the accumulation of glucosylceramide in the monocyte-macrophage system (4). In peripheral blood leukocytes, a finding of less than $15 \%$ in the mean $\beta$-glucocerebrosidase activity measurement is diagnostic, and diagnoses can be confirmed through a GBA gene analysis. More than 350 different mutant GBA alleles have been identified (5).

In this report, we describe the clinical features, laboratory parameters and molecular characteristics of 18 non-neuronopathic adult Gaucher patients, as well as the hematological, skeletal and visceral responses of 15 patients who underwent ERT.

\section{Material and Methods}

An analysis was made of adult nonneuronopathic Gaucher patients who were diagnosed and followed by the Eskişehir Osmangazi University Pediatric Metabolism and Adult Hematology Units from January 2000 to January 2020.

\section{Laboratory, visceral and skeletal findings}

The hematological parameters, visceral findings and biochemical parameters at the start of treatment, in the 1st year, in the 2nd year and at the final visit were recorded. The criteria for anemia, thrombocytopenia and neutropenia are presented in Table-1 (6). Enlargements of the liver and spleen were assessed through a physical examination and ultrasound. The mean within-patient changes from baseline to pre-defined time points were calculated for $\mathrm{Hb}$ concentrations, platelet (PLT) and white blood cell (WBC) counts, liver and spleen sizes, and bone mineral density (BMD) records [evaluated using dualenergy X-ray absorptiometry (DEXA) (lumbar spine, femur)]. A BMD T-score of 2.5 or less classified as osteoporosis, and between -1.0 and -2.5 was classified as osteopenia.

Tablo 1. The criteria for anemia, thrombocytopenia and neutropenia (6)

\begin{tabular}{|c|c|}
\hline Definition & Values \\
\hline Anemia & $\begin{aligned} \text { Hb concentration } & <9.5 \mathrm{gr} / \mathrm{dL} \text { for infants }(6 \text { months- } 2 \text { years }) \\
& <10.5 \mathrm{gr} / \mathrm{dL} \text { for children }(2-12 \text { years }) \\
& <11 \mathrm{~g} / \mathrm{dL} \text { for pregnant women } \\
& <12 \mathrm{~g} / \mathrm{dL} \text { for females } \\
& <13 \mathrm{~g} / \mathrm{dL} \text { for males }\end{aligned}$ \\
\hline $\begin{array}{r}\text { Thrombocytopenia } \\
\text { Mild } \\
\text { Moderate } \\
\text { Severe }\end{array}$ & 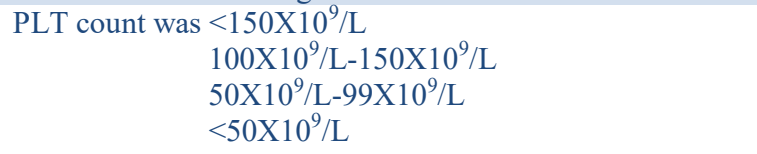 \\
\hline Neutropenia & WBC count was $<4500 / \mathrm{mm}^{3}$ \\
\hline
\end{tabular}

Hb: hemoglobin, PLT: platelet, WBC: leukocyte 
Enzymatic analysis and genetic mutation studies

All patients were diagnosed with low $\beta$ glucocerebrosidase enzyme activity in driedblood spot samples. Genetic analyses were conducted to confirm the diagnosis, and also to determine the specific type of mutation in the GBA gene.

\section{Statistical analysis}

The statistical evaluation of the data was conducted using IBM SPSS Statistics (Version 21.0. Armonk, NY: IBM Corp.). Quantitative variables were expressed as mean \pm standard deviation or median $(\mathrm{Q} 1-\mathrm{Q} 3)$, while qualitative variables were expressed as frequency and percentages. The compatibility to the normal distribution of the differences between quantitative variables was evaluated with a Kolmogorov-Smirnov test. In treated patients, the changes in the variables compatible with a normal distribution between the results at the outset, and at the $1 \mathrm{st}$ year, 1st-2nd year, 2nd year-final visit were investigated with a Paired samples T-test, and those that didn't fit the normal distribution were assessed with a Wilcoxon test. A MannWhitney $U$ test was used to compare the splenectomized and non-splenectomized patients. $\mathrm{p}<0.05$ was deemed to indicate statistical significance.

\section{Results}

There were 18 patients (six males, 12 females) with two sibling pairs from consanguineous pedigrees, aged at the time of the study from 21-68 years. The median age at the onset of clinical manifestations was 21 years (1.6-63) and the confirmation of diagnosis was 25 years (2-65). There was a delay of a mean 3.56 years $(0-21$ years $)$ from the time of symptom onset to diagnosis.

The baseline demographic characteristics of 18 patients are summarized in Table-2. One patient was referred to the hematology clinic due to postpartum hemorrhage and thrombocytopenia, and another patient due to pancytopenia after contracting flu. In a patient presenting with itching without hepatosplenomegaly, randomly detected thrombocytopenia led to a diagnosis of GD based on a bone marrow smear (BMS). Another patient with a history of splenectomy was investigated for leukocytosis and GD was diagnosed from the appearance of Gaucher cells in the BMS. A woman with a massive splenomegaly passed away due to renal insufficiency, one month after diagnosis. Four patients were diagnosed following family screening, and one of these was excluded from the study as she was under the age of 18 . Two cases were the mothers of the index cases, and one of these patients refused treatment, while the other patient couldn't be treated as she had no health insurance, and left the follow-up. The fourth patient detected during screening had hepatosplenomegaly. The most common complaint of the five patients diagnosed in childhood was abdominal distension, with hepatosplenomegaly and pancytopenia being common findings. Three patients had pathology results indicating GD, but were unaware of the diagnosis and consulted different doctors for many years, among which, one was diagnosed while being investigated for the etiology of cirrhosis and esophageal varicose bleeding, having a history of splenectomy 14 years prior to diagnosis. The other 35-year-old woman was diagnosed with hepatosplenomegaly and pancytopenia during pregnancy, and had undergone a bone marrow biopsy five years before that indicating GD. The last one was a 65 -year-old male patient who was diagnosed during an etiological search for hyperferritinemia and mild splenomegaly, and who had undergone a hepatic biopsy three years earlier indicating GD. The remaining two female patients were diagnosed while being investigated for the etiology of organomegaly. 
Table-2. Baseline demographic characteristics of 18 patients

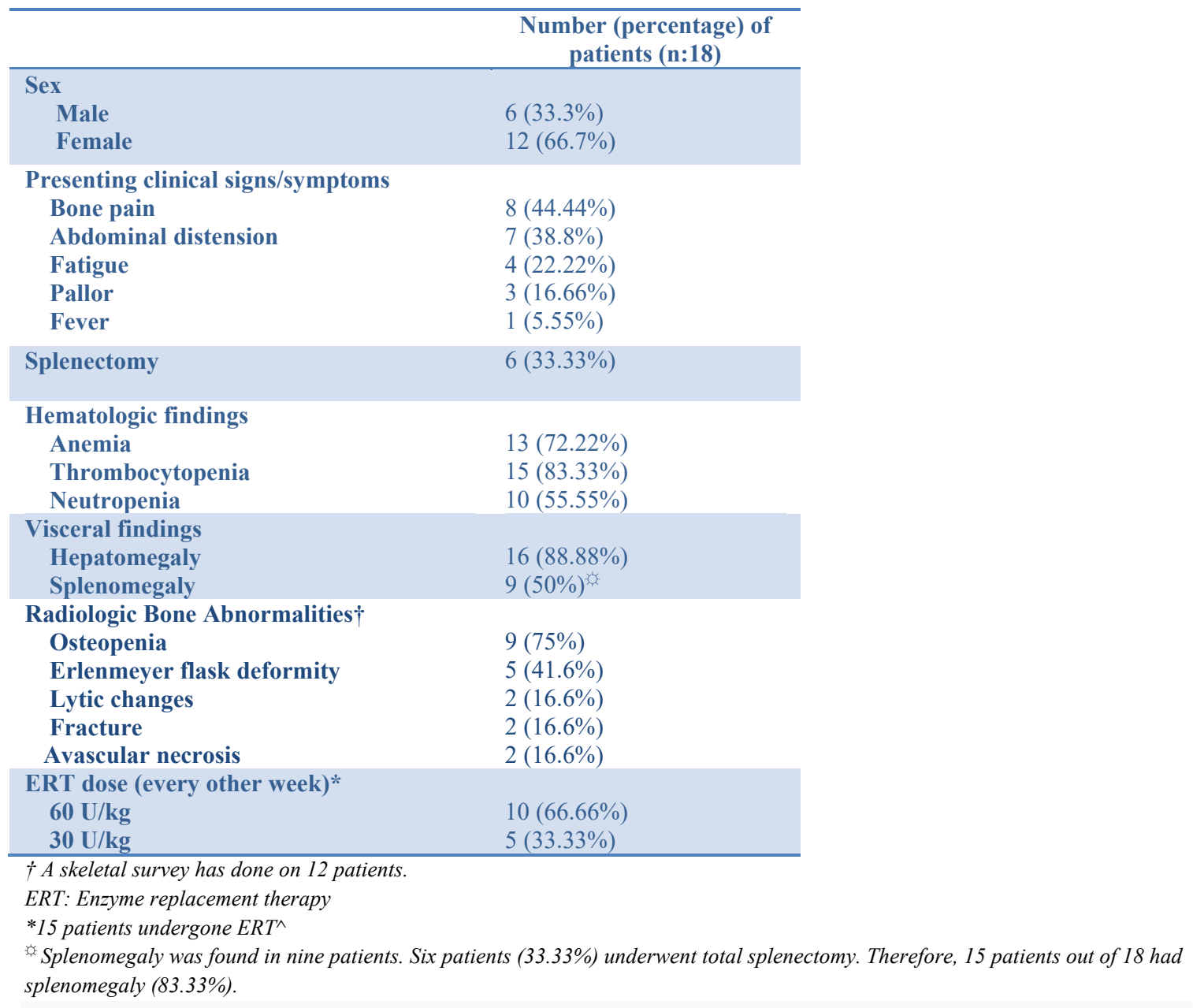

The initial median hematological and biochemical parameter values are summarized in Table-3. Anemia was found in 13 patients; three patients had $\mathrm{Hb}$ concentrations of less than $8 \mathrm{~g} / \mathrm{dL}$, two had concentrations of between 8 and $10 \mathrm{~g} / \mathrm{dL}$. Severe thrombocytopenia was detected in one, moderate thrombocytopenia in nine and mild thrombocytopenia in five patients. Pancytopenia was detected in 12 patients. Aspartate aminotransferase was elevated in two patients, and alanine aminotransferase was slightly elevated in one patient. Of the total, 10 patients had initial ferritin data, and 12 of the treated patients had ferritin values from the final visit. The median ferritin value at diagnosis was $575.35 \mathrm{ng} / \mathrm{mL}$ and 124.00 $\mathrm{ng} / \mathrm{mL}$ at the final control $(\mathrm{p}=0.036)$. The baseline ferritin values were significantly higher in the patients with hepatomegaly $(p=0.005)$. There was no significant difference in the ferritin levels of the patients with and without splenectomy $(p>0.05)$.

Table-3. The initial median values of hematological and biochemical parameters of 18 patients

\begin{tabular}{lcccccc}
\hline & Hb $(\mathbf{g} / \mathbf{d L})$ & PLT $\left(\mathbf{x 1 0} \mathbf{9}^{\mathbf{L}}\right)$ & WBC $\left(\mathbf{m m}^{\mathbf{3}}\right)$ & ALT (IU) & AST (IU) & Ferritin (ng/mL) \\
\hline Median & 11.65 & 89.5 & 4400 & 25 & 32.5 & 575.35 \\
$($ Q1-Q3) & $(8.92-12.45)$ & $(66.0-135.25)$ & $(2597.5-8600)$ & $(14.5-31.75)$ & $(25.5-43.25)$ & $(170.42-1578.75)$ \\
\hline
\end{tabular}

Hb: Hemoglobin, PLT: Platelets, WBC: Leucocytes, ALT: Alanine aminotransferase, AST: Aspartate minotransferase 
In the first year of treatment, the increase in $\mathrm{Hb}$ concentrations was more dramatic $(p=0.005)$. Median serum $\mathrm{Hb}$ levels were significantly higher after ERT when compared to the baseline levels $(\mathrm{p}<0.05) \quad($ Table-4). There was no statistically significant difference between those with and without splenectomy in the recovery rates of anemia $(p>0.05)($ Table-5). The increase in PLT count was more pronounced in the first year of therapy $(p=0.002)$, but there was no significant difference between 1st-2nd year. There was a statistically significant difference between the splenectomized and nonsplenectomized patients in terms of thrombocytopenia and neutropenia recovery rates $(p<0.05)($ Table-5).

Table-4. Summary of hematologic parameters of treated 15 patients at baseline and on follow-up

\begin{tabular}{|c|c|c|c|c|c|}
\hline & & Mean \pm SD & (Q1-Q3) & $p^{* W}$ & \\
\hline \multirow{5}{*}{ Hemoglobin (g/dL) } & At start of ERT & $10.76 \pm 2.15$ & 11.50 & $8.40-12.40$ & \\
\hline & After 1 year & $12.30 \pm 2.68$ & 12.0 & $10.50-14.50$ & 0.005 \\
\hline & After 2 years & $13.35 \pm 1.87$ & 13.20 & $11.90-14.80$ & 0.006 \\
\hline & At last visit & $14.33 \pm 1.53$ & 14.30 & $13.0-15.50$ & 0.019 \\
\hline & At start of ERT & $123.133 \pm 74.895$ & 95.0 & $67.0-148.0$ & \\
\hline \multirow{4}{*}{ Platelets $\left(x 10^{9} / \mathrm{L}\right)$} & After 1 year & $182.06 \pm 157.73$ & 140.0 & $84.0-248.0$ & 0.002 \\
\hline & After 2 years & $189.40 \pm 106.79$ & 156.0 & $105.0-360.0$ & 0.211 \\
\hline & At last visit & $219.86 \pm 88.58$ & 219.0 & $124.0-303.0$ & 0.036 \\
\hline & At start of ERT & $6673.33 \pm 5025.43$ & 4400.0 & $3600.0-9800.0$ & \\
\hline \multirow{3}{*}{ Leucocytes $\left(\mathrm{mm}^{3}\right)$} & After 1 year & $6261.33 \pm 2860.79$ & 5300.0 & $4200.0-7500.0$ & 0.730 \\
\hline & After 2 years & $6810.00 \pm 2706.88$ & 6250.0 & $5100.0-7180.0$ & 0.112 \\
\hline & At last visit & $6793.07 \pm 2255.75$ & 6380.0 & $5400.0-7640.0$ & 0.875 \\
\hline
\end{tabular}

SD: Standart deviation; ERT: Enzyme replacement therapy; *: $p<0.05$ : Statistically significant; ${ }^{W}:$ Wilcoxon test

Table-5. Summary of hematologic parameters of splenectomized and non-splenectomized treated

\begin{tabular}{|c|c|c|c|c|c|c|}
\hline & & \multicolumn{2}{|c|}{$\begin{array}{c}\text { Non-splenectomized } \\
(\mathrm{n}: 7)\end{array}$} & \multicolumn{2}{|c|}{$\begin{array}{c}\text { Splenectomized } \\
(\mathrm{n}: 6)\end{array}$} & \multirow[t]{2}{*}{$\mathbf{p}^{* \mathrm{M}}$} \\
\hline & & Median & Q1-Q3 & Median & Q1-Q3 & \\
\hline \multirow{3}{*}{ Baseline } & $\mathrm{Hb}(\mathrm{g} / \mathrm{dL})$ & 11.10 & $8.10-11.90$ & 12.30 & $10.20-12.70$ & 0.216 \\
\hline & $\operatorname{PLT}\left(\times 10^{9} / \mathrm{L}\right)$ & 81.00 & $62.50-115.50$ & 190.50 & $87.00-259.25$ & 0.045 \\
\hline & WBC $\left(\mathrm{mm}^{3}\right)$ & 4300 & $2550-4700$ & 10400 & $4800-17100$ & 0.013 \\
\hline \multirow{3}{*}{ 1st year } & Hb (g/dL) & 12.00 & $9.45-13.45$ & 13.10 & $10.55-16.42$ & 0.316 \\
\hline & $\operatorname{PLT}\left(\times 10^{9} / L\right)$ & 90.00 & $63.50-149.00$ & 277.0 & $129.5-423.00$ & 0.018 \\
\hline & $\operatorname{WBC}\left(\mathrm{mm}^{3}\right)$ & 4750 & $3850-6530$ & 8250 & $4925-11675$ & 0.059 \\
\hline \multirow{3}{*}{ 2nd year } & Hb (g/dL) & 12.80 & $11.50-13.65$ & 14.40 & $12.87-16.275$ & 0.059 \\
\hline & $\operatorname{PLT}\left(\times 10^{9} / \mathrm{L}\right)$ & 119.00 & $88.50-169.00$ & 265.50 & $204.47-379.50$ & 0.005 \\
\hline & $\mathrm{WBC}\left(\mathrm{mm}^{3}\right)$ & 5200 & $4550-6860$ & 7050 & $6225-12450$ & 0.034 \\
\hline \multirow{3}{*}{ Last visit } & $\mathrm{Hb}(\mathrm{g} / \mathrm{dL})$ & 13.80 & $12.40-15.20$ & 14.90 & $14.02-16.46$ & 0.126 \\
\hline & $\operatorname{PLT}\left(\times 10^{9} / \mathrm{L}\right)$ & 187.00 & $114.00-226.00$ & 298.00 & $243.25-336.75$ & 0.013 \\
\hline & $\mathrm{WBC}\left(\mathrm{mm}^{3}\right)$ & 5430 & $4540-6590$ & 8638 & $6635-10650$ & 0.005 \\
\hline
\end{tabular}

patients

*: $p<0.05$ : Statistically significant; ${ }^{M}:$ Mann-Whitney U test, Hb: Hemoglobin, PLT: Platelets, WBC: Leucocytes

Hepatomegaly was identified as an initial finding in 16 patients $(88.8 \%)$ and splenomegaly was found in nine while six patients $(33.33 \%)$ underwent a total splenectomy, indicating that 15 patients of the
18 had splenomegaly (83.33\%). Four patients diagnosed in childhood had a history of splenectomy within the first decade. On ultrasound, the mean liver span had an average of $174.44 \pm 27.80 \mathrm{~mm}$ at the mid- 
clavicular line (range 116-215 mm). The mean spleen size was $187.50 \pm 61.09 \mathrm{~mm}$ (range 100-300 $\mathrm{mm}$ ) in the 12 nonsplenectomized patients.

Table- 2 provides a summary of the radiologic bone anomalies of 12 patients. Four patients had osteopenia, and five had osteoporosis, as determined by BMD.

All patients recorded low activity of the $\beta$ glucocerebrosidase enzyme. The median enzyme activity was $0.36 \mathrm{nmol} / \mathrm{hour} / \mathrm{mg}$ protein (0-2.70). Twelve patients had bone marrow aspiration, all of whom displayed the characteristic "Gaucher cells". The most common mutant allele detected was N409S; and L483P and S405T mutations were also reported. Ten of the non-splenectomized patients had the homozygous N409S mutation (Table-6). Lyso GL-1 which is a key biomarker of GD, was identified in eight patients at the outset, and was found to be elevated in all (mean $113 \pm 28.9 \mathrm{ng} / \mathrm{ml}$ ).

Table-6. Genetic status and enzyme levels of the patients

\begin{tabular}{|c|c|c|c|c|c|c|c|}
\hline \multicolumn{4}{|c|}{ Non-splenectomized patients } & \multicolumn{4}{|c|}{ Splenectomized patients } \\
\hline & $\begin{array}{c}\text { GC in bone } \\
\text { marrow } \\
\text { smear }\end{array}$ & $\begin{array}{l}\text { Enzyme } \\
\text { level* }\end{array}$ & Genetic status & & $\begin{array}{l}\text { GC in bone } \\
\text { marrow smear }\end{array}$ & $\begin{array}{l}\text { Enzyme } \\
\text { level* }\end{array}$ & Genetic status \\
\hline 1 & + & 0.2 & N409S/N409S & 13 & + & 1,24 & N409S/L483P \\
\hline 2 & + & 0.3 & N409S/N409S & 14 & - & $2,70^{\gamma}$ & N409S/? \\
\hline 3 & - & 0.23 & N409S/N409S & 15 & - & 0.30 & N409S/? \\
\hline 4 & + & 0.36 & N409S/N409S & 16 & + & 0.30 & N409S/N409S \\
\hline 5 & + & 0.73 & N409S/N409S & 17 & + & 1.5 & L483P/L483P \\
\hline 6 & + & 0.0 & N409S/N409S & 18 & + & 1.86 & N409S/L483P \\
\hline 7 & + & 0.10 & $\mathrm{~S} 405 \mathrm{~T} / \mathrm{S} 405 \mathrm{~T}$ & & & & \\
\hline 8 & - & 0.6 & N409S/N409S & & & & \\
\hline 9 & + & 0.4 & N409S/N409S & & & & \\
\hline 10 & + & $2.5^{\gamma}$ & N409S/N409S & & & & \\
\hline 11 & - & 0.2 & N409S/? & & & & \\
\hline 12 & - & & N409S/N409S & & & & \\
\hline
\end{tabular}

Of the total, 15 patients underwent ERT (10 patients with $60 \mathrm{U} / \mathrm{kg}$ doses, five patients with $30 \mathrm{U} / \mathrm{kg}$ doses every other week) with imiglucerase (Cerezyme ${ }^{\circledR}$; Genzyme, a Sanofi company) (Table-2). The median age at treatment onset was 27.75 years $(2.5-65)$. Overall, it took an average of 5.82 years $(0-$ 33) from the confirmation of diagnosis to the initiation of treatment. ERT was unavailable in Turkey prior to 2007, and so four patients were able to start therapy only years after their diagnosis, two of which underwent a splenectomy for hypersplenism in this period.
The median follow-up period of the 15 patients was five years (2.5-20) and the mean duration of ERT was 6.33 years (2.5-13).

The results revealed significant decreases in liver size in the first year of ERT $(p<0.05)$ (Table-7), with no statistically significant difference recorded in the reduction of liver size between the splenectomized and nonsplenectomized patients $(\mathrm{p}>0.05)$ (Table-8). The reduction in spleen size was more prominent from the second year onward $(\mathrm{p}<0.018)($ Table-7). 
Table-7. Summary of visceral findings and BMD at baseline and on follow-up of treated patients

\begin{tabular}{|c|c|c|c|c|c|}
\hline & Me & Median & (Q1-Q3) & $\mathbf{p}^{* W}$ & \\
\hline \multirow{5}{*}{ Liver size $(\mathrm{mm})$} & At start of ERT & $175.33 \pm 29.84$ & 180.00 & $165.00-196.00$ & \\
\hline & After 1 year & $163.13 \pm 26.02$ & 165.00 & $148.00-182.00$ & 0.006 \\
\hline & After 2 years & $158.53 \pm 22.48$ & 155.00 & $145.00-181.00$ & 0.051 \\
\hline & At last visit & $153.73 \pm 20.89$ & 153.00 & $145.00-160.00$ & 0.255 \\
\hline & At start of ERT & $201.11 \pm 60.53$ & 185.00 & $153.00-256.00$ & \\
\hline \multirow{4}{*}{$\begin{array}{l}\text { Spleen size }(\mathrm{mm})^{\mathrm{a}} \\
\text { (non-splenectomized } \\
\text { patients) }\end{array}$} & After 1 year & $183 \pm 42.02$ & 176.00 & $146.50-207.50$ & 0.51 \\
\hline & After 2 years & $170.44 \pm 34.95$ & 155.00 & $144.00-201.00$ & 0.018 \\
\hline & At last visit & $144.55 \pm 28.18$ & 144.00 & $127.50-157.50$ & 0.020 \\
\hline & At start of ERT & $-1.73 \pm 1.24$ & -1.65 & $(-2.65)-(-0.97)$ & \\
\hline \multirow{2}{*}{$\begin{array}{l}\text { BMD T-score } \\
\text { (Lomber spine) }\end{array}$} & After 1 year & $-1.62 \pm 1.15$ & -1.55 & $(-2.72)-(-0.95)$ & 0.141 \\
\hline & After 2 years & $-1.39 \pm 1.08$ & -1.15 & $(-2.32)-(-0.80)$ & 0.019 \\
\hline \multirow{5}{*}{$\begin{array}{l}\text { BMD T-score } \\
\text { (Femur neck) }\end{array}$} & At last visit & $-1.05 \pm 1.57$ & -1.00 & $(-2.27)-(-0.35)$ & 0.195 \\
\hline & At start of ERT & $-1.37 \pm 1.04$ & -1.45 & $(-2.27)-(-0.95)$ & \\
\hline & After 1 year & $-1,35 \pm$ & -1.45 & $(-2.02)-(-0.75)$ & 0.526 \\
\hline & After 2 years & $-1,14 \pm$ & -1.25 & $(-1.9)-(-0.30)$ & 0.021 \\
\hline & At last visit & $-1,04 \pm$ & -1.1 & $(-2.05)-(0.75)$ & 0.476 \\
\hline
\end{tabular}

BMD: Bone Mineral Density; ${ }^{*} p<0.05$ : Statistically significant, ${ }^{a}$ Nine non-splenectomized patients

BMD improved slowly with ERT, and significant improvement was achieved in both the lumbar spine and femoral neck T-scores between the first and second years of treatment $(p<0.05)($ Table-7). There was no statistically significant difference in the osteopenia recovery rates of the splenectomized and non-splenectomized patients $(p>0.05)($ Table- 8$)$.

Table-8: Summary of ultrasound and BMD results of splenectomized and non-splenectomized treated patients

\begin{tabular}{|c|c|c|c|c|c|c|}
\hline & & \multicolumn{2}{|c|}{$\begin{array}{c}\text { Non-splenectomized } \\
(n: 7)\end{array}$} & \multicolumn{2}{|c|}{$\begin{array}{l}\text { Splenectomized } \\
\text { (n:6) }\end{array}$} & \multirow[t]{2}{*}{$p^{* M}$} \\
\hline & & Median & Q1-Q3 & Median & Q1-Q3 & \\
\hline \multirow{3}{*}{ Baseline } & Liver size (mm) & 190.00 & $170.00-206.25$ & 175.00 & $152.75-197.00$ & 0.636 \\
\hline & $\begin{array}{l}\text { BMD T-score } \\
\text { (Femur neck) }\end{array}$ & -1.60 & $(-2.12)-(-1.29)$ & -1.15 & $(-2.5)-(-0.25)$ & 0.438 \\
\hline & $\begin{array}{l}\text { BMD T-score } \\
\text { (Lomber spine) }\end{array}$ & -1.60 & $(-2.49)-(-0.96)$ & -2.10 & $(-3.35)-(-0.67)$ & 0.438 \\
\hline \multirow{3}{*}{ 1st year } & Liver size (mm) & 178.50 & $157.50-188.75$ & 156.50 & $126.25-176.50$ & 0.175 \\
\hline & $\begin{array}{l}\text { BMD T-score } \\
\text { (Femur neck) }\end{array}$ & -1.45 & $(-2.00)-(-1.00)$ & -1.45 & $(-2.15)-(-0.15)$ & 0.897 \\
\hline & $\begin{array}{l}\text { BMD T-score } \\
\text { (Lomber spine) }\end{array}$ & -1.50 & $(-2.10)-(-0.85)$ & -2.15 & $(-3.05)-(-0.70)$ & 0.366 \\
\hline \multirow{4}{*}{ 2nd year } & Liver size (mm) & 162.50 & $151.25-185.00$ & 152.50 & $132.50-169.00$ & 0.375 \\
\hline & $\begin{array}{l}\text { BMD T-score } \\
\text { (Femur neck) }\end{array}$ & -1.25 & $(-2.10)-(-0.50)$ & -1.15 & $(-1.90)-(-0.60)$ & 0.604 \\
\hline & $\begin{array}{l}\text { BMD T-score } \\
\text { (Lomber spine) }\end{array}$ & -1.05 & $(-1.97)-(-0.80)$ & -1.80 & $(-2.87)-(-0.53)$ & 0.332 \\
\hline & Liver size (mm) & 150.00 & $145.75-176.50$ & 154.00 & $125.75-160.00$ & 0.636 \\
\hline
\end{tabular}




\begin{tabular}{cccccc}
\hline Last visit $\begin{array}{l}\text { BMD T-score } \\
\text { (Femur neck) }\end{array}$ & -1.20 & $(-2.42)-(-0.22)$ & -0.80 & $(-2.00)-(-0.25)$ & 0.650 \\
$\begin{array}{l}\text { BMD T-score } \\
\text { (Lomber spine) }\end{array}$ & -1.00 & $(-2.32)-(-0.25)$ & -1.30 & $(-2.35)-(-0.50)$ & 0.846 \\
\hline$*: p<0.05:$ Statistically significant; ${ }^{M}:$ Mann-Whitney U test, BMD: Bone mineral density &
\end{tabular}

During follow-up, complications such as pulmonary hypertension (PH), avascular necrosis and gaucheroma were observed. Two patients had healthy pregnancies with ERT and had healthy babies. No malignancy has yet been detected in any patient.

\section{Discussion}

It is known that there can be several years between the onset of symptoms and the diagnosis and treatment of GD. Most of the patients in the present study had severe symptoms at the outset, and the delay in diagnosis was most likely associated with a lack of knowledge of the need to include GD in a differential diagnosis. Despite the fact that three of our patients had a pathology report supporting GD, they were unaware of their diagnosis, and their care was delayed for years as they were not recommended to see a specialist, or were unable to find one.

In the present study, only five patients (33.25\%) were diagnosed before 10 years of age, with the mean age of diagnosis of the remaining 13 patients being 28.7 years. Despite early manifestations, there was a delay of a mean 3.56 years (0-21) from the time of symptom onset to diagnosis, with the delay being more pronounced in adult patients. The International Collaborative Gaucher Group (ICGG) Gaucher Registry found that the majority of non-neuronopathic GD cases were symptomatic during childhood and adolescence, with $49 \%$ of cases diagnosed before 10 years of age, and $17 \%$ between the ages of 11 and 20 years (7). A further study reported a mean age of symptom onset of 15 $(0-77)$ years, and a mean age of diagnosis of $22(0-84)$ years $(8)$. In our cohort, the median age at diagnosis was 27 years $(20-40.5)$ in non-splenectomized patients, and 3.8 years (324.25) in splenectomized patients. In Weinreb's (9) study of 757 Gaucher patients, the median age at diagnosis was 11 years in non-splenectomized patients and 10 years in splenectomized patients.

In Turkey, where consanguineous marriage is common, the family screening of index patients is critical. In this study, four of the 18 patients were diagnosed in this manner, with two being the mothers of index cases.

The patients saw significant improvement in their $\mathrm{Hb}$ concentrations during the first year of treatment, continuing into the following period. At the last visit, the mean $\mathrm{Hb}$ level was no different to the normal population. As the therapeutic goal, PLT counts are expected to rise 1.5 times by year 1 , and to continue for the next 2-5 years (10). In our cohort, baseline thrombocytopenia was present in $83.33 \%$ of the patients, and the increases in PLT count were more pronounced in the first year. One patient who did not achieve a normal PLT count by the second year had a massive splenomegaly at baseline. There was a statistically significant difference between the splenectomized and non-splenectomized patients in terms of thrombocytopenia and neutropenia recovery rates from the baseline to the defined time points. While splenectomy improves cytopenias, it is not advised, as ERT also improves hematological parameters quickly. Splenectomy can cause serious bone complications. The presence of bone symptoms is one of the leading indicators of morbidity. This rare metabolic disease, which can be easily diagnosed and treated, should be kept in mind in patients considering invasive procedures such as splenectomy. Hepatomegaly was found in $88.8 \%$ of our patients, and splenomegaly in $50 \%$, and when the six splenectomized patients were included, 15 of the 18 patients had splenomegaly. As with the hematologic response, the examination of cross-sectional visceral findings showed continued improvement over the follow-up periods.

Significant improvements were identified in the T-scores only between the first and second years. In fact, the patients with splenectomy recorded worse $\mathrm{T}$-scores and had a lower response to therapy. While the small number of patients may be a factor, no statistically significant difference was noted between the splenectomized and non-splenectomized patients in terms of osteopenia recovery rates. Charrow (11) reported that BMD slowly improves with ERT. 
In our study, eight patients reported bone crisis before starting ERT, and three patients while receiving treatment. After four years of ERT, new bone crises were experienced in these patients. Generalized or localized chronic bone pain has been reported in 49$82 \%$ of GD patients prior to the initiation of therapy $(7,12)$. In the ICGG Gaucher Registry cohort, $49 \%$ of patients reported bone pain before beginning ERT, and only $30 \%$ after one-year of treatment (7). Avascular necrosis, especially of the femoral head, is a well-known but unpredictable complication. In two splenectomized patients with heterozygous N409S, avascular necrosis was discovered and a hip replacement was made.

GD should be ruled out in cases of hyperferritinemia with an unknown cause, as first reported by Morgan et al. (13). Mekinian (14) reported the frequency of hyperferritinemia in untreated patients to be $87 \%$, with a median of $739 \mu \mathrm{g} / \mathrm{L}$. The ferritin levels in the patients in the present study reduced significantly as a result of therapy. Basal ferritin values increased as the liver size increased. Chitotriosidase, CCL18, serum angiotensin-converting enzyme and tartrateresistant isoenzyme may be used as activated macrophages biomarkers (1), and for monitorization in treated patients. It should be kept in mind that $6 \%$ of the population has no chitotriosidase activity. We were unable to study these biomarkers in our center. Plasma glucosylsphingosine (Lyso GL-1) is a valuable biomarker for the diagnosis and tracking of GD. Dekker (15) reported Lyso GL-1 to be increased in $100 \%$ of GD patients with high specificity. Lyso GL-1 has no gender-dependent level and has superior characteristics over the other two biomarkers, CCL18 and chitotriosidase, in terms of diagnostic utility (16). Lyso GL-1 levels were significantly high in eight of the patients who were able to be tested, but decreased with ERT.

Similar to literature, N409 allele was found more frequently in the present study $(61.11 \%$ patients were homozygous for N409S). A heterozygous N409S mutation was detected in three patients with a low enzyme activity L483P and S405T mutations were also found. Cabrera (17) reported N409S to be the most frequent allele $(26.9 \%)$, followed by L483P (13.4\%). In a patient with splenectomy at the age of two who was diagnosed with GD at the age of 23 , a L483P/L483P mutation was detected, while no neurological findings were identified in this patient, either at the time of diagnosis or during the 4-year follow-up. Goker-Alpan first described the susceptibility of carriers of GBA mutations to Parkinson's disease (18). In heterozygosity, the variants p.R159W, p.N227S, p.G416S and p.L483P have been linked to familial Parkinson's disease among Asian populations (19). Since there is a pseudogene (GBAP) next to the GBA main gene, there are frequent segment changes between these two genes, and three or four mutations may be observed simultaneously in the same patient, known also as recombinant alleles. We detected $\mathrm{N} 409 \mathrm{~S} / \mathrm{L} 483 \mathrm{P}$ in allele one and L483P/D448H in the other allele in a female patient whose mother was found to be a carrier of N409S, and her father to be a carrier of L483P. A neurological examination of this interesting patient was completely normal. Since the patient carries N409S, it is probably neurologically preserved, although it does raise a curiosity of how the clinical course will be in the presence of these different mutations.

In the present study, 15 patients underwent imiglucerase (Cerezyme $\left.{ }^{\circledR}\right)$ treatment. Recombinant human acid $\beta$-glucosidase ERT has been the first-line treatment for nonneuronopathic GD (10). It has been available since 1991 and is well-established, with known efficacy and minimal toxicity. Although the response to treatment varies from patient to patient, and depends upon organ involvement, improvement is reported in all clinical and laboratory parameters with ERT. The age at treatment initiation and ERT dosage affect the occurrence of permanent complications such as osteonecrosis (20). Imiglucerase, taliglucerase alfa and velaglucerase alfa are all currently available in Turkey. There is no risk in administering ERT during pregnancy. Two of the patients in the present study became pregnant during treatment, and neither experienced complications during pregnancy or delivery. Substrate reduction therapy (SRT) is an alternative treatment that seeks to regulate the development of glucosylceramide by partially 
inhibiting glucosylceramide synthase, as the glycosphingolipid biosynthesis rate-limiting step (21).

A patient with the heterozygous N409S mutation developed $\mathrm{PH}$ in the fourth year of therapy. A previous review of 98 Gaucher patients found $\mathrm{PH}$ to be present in $30 \%$ of those who did not undergo ERT and in 7.4\% of those who did (22). Gaucheroma was detected in the ovary of a female patient and in the liver of a male patient. No malignancy developed in the patients in this study during follow-up. The risk of multiple myeloma, non-Hodgkin lymphoma, liver cancer, kidney cancer and melanoma in patients increases in all age groups when compared to the general population. During follow-up, cancer screening is important, and it should be emphasized that the impact on carcinogenesis and cancer immunology of sphingolipid substrates and metabolites should be examined.

In conclusion, quality of life can be improved and lifelong complications can be eliminated

\section{REFERENCES}

1. Gary, S.E, Ryan, E, Steward, A.M, Sidransky, E. Recent advances in the diagnosis and management of Gaucher disease. Expert Rev. Endocrinol. Metab. 2018; 13; 107-118.

2. Saudubray JM, Baumgartner MR, Walter J. Disorders of Sphingolipid Synthesis, Sphingolipidoses, Niemann Pick Disease Type-C and Neuronal Ceroid-Lipofuscinoses. Gaucher Disease: In Sphingolipidoses. Inborn Metabolic Diseases Diagnosis and Treatment 6th Edition. Springer Berlin, Heidelberg 2016;38: 556-59.

3. Nalysnyk L, Rotella P, Simeone JC, et al. Gaucher disease epidemiology and natural history: a comprehensive review of the literature. Hematology 2017; 22: 65-73.

4. Grabowski GA. Phenotype, diagnosis and treatment of Gaucher's disease. Lancet 2008; 372: 1263-1271.

5. Carla E.M. Hollak. Gaucher Disease. In: Carla E.M. Hollak, Lachmann R.H (eds). Inherited Metabolic Disease in Adults. New York, Oxford University Press, 2016

6. Donald M Arnold, Adam Cuker, Approach to the adult with unexplained thrombocytopenia. UpToDate 2020

7. Charrow J, Andersson HC, Kaplan P, et al. The Gaucher Registry: demographics and disease characteristics of 1698 patients with Gaucher disease. Arch Intern Med. 2000; 160: 2835-43

8. Stirneman J, Vigan M, Hamroun D et el. The French Gaucher's disesase Registry: Clinical characteristics complications and treatment of 562 patients. Orphanet J Rare Dis 2012; 7: 77 with the early diagnosis and treatment of GD. Physicians, particularly those engaged in hematology and internal medicine, should suspect GD in any adult patient with bone pain and unexplained hematologic dysfunction, especially in the presence of organomegaly. A multidisciplinary team approach that involves disease-specific therapies, as well as supportive care, is needed for the management of multisystemic symptoms.

\section{Acknowledgment}

We would like to thank Professor Sultan D. Aydoğdu, who we remember with respect.

\section{Ethics Committee Approval}

Ethics committee approval was obtained from the Eskisehir Osmangazi University Medical Faculty Ethics Committee with decision number 25403353-050.99-E.76070, decision no: 40. This study was conducted in accordance with the Declaration of Helsinki of the World Medical Association (2000).

9. Neal J. Weinreb \& Jack Goldblatt \& Jacobo Villalobos \& Joel Charrow \& J. Alexander Cole \& Marcelo Kerstenetzky \& Stephan vom Dahl \& Carla Hollak. Long-term clinical outcomes in type 1 Gaucher disease following 10 years of imiglucerase treatment. J Inherit Metab Dis 2013; 36: 543-53

10. Pastores G.M, Weinreb N.J, Aerts H, Andria G, Cox T.M, Giralt M, Grabowski G.A, Mistry P.K, Tylki-Szymańska A. Therapeutic goals in the treatment of Gaucher disease, Semin. Hematol. 2004; 41: 4-14.

11. Charrow J, Scott C.R. Long-term treatment outcomes in Gaucher disease. Am. J. Hematol. 2015; 90: 19-24.

12. Charrow J, Dulisse B, Grabowski GA, Weinreb NJ. The effect of enzyme replacement therapy on bone crisis and bone pain in patients with type 1 Gaucher disease. Clin Genet 2007; 71: 205-211.

13. Morgan M.A, Hoffbrand A.V, Laulicht M, Luck $\mathrm{W}$, Knowles S. Serum ferritin concentration in Gaucher's disease, BMJ 1983; 286: 1864.

14. Mekinian A, Stirnemann J, Belmatoug N, Heraoui D, Fantin B, Fain O, Charpentier A, Rose C. Ferritinemia during type 1 Gaucher disease: Mechanisms and progression under treatment. Blood Cells, Molecules and Diseases 2010; 49: 53-57.

15. Dekker N, van Dussen L, Hollak C.E, Overkleeft H, Scheij S, Ghauharali K, van Breemen M.J, Ferraz M.J, Groener J.E, Maas M, Wijburg F.A, Speijer D, Tylki-Szymanska A, Mistry P.K, Boot R.G, Aerts J.M. Elevated plasma glucosylsphingosine in Gaucher disease: relation 
to phenotype, storage cell markers, and therapeutic response, Blood 2011; 118: e118-e127.

16. Rolfs A, Giese A.K, Grittner U, Mascher D, Elstein D, Zimran A, Bottcher T, Lukas J, Hubner R, Golnitz U, Rohle A, Dudesek A, Meyer W, Wittstock M, Mascher H. Glucosylsphingosine is a highly sensitive and specific biomarker for primary diagnostic and follow-up monitoring in Gaucher disease in a non-Jewish, Caucasian cohort of Gaucher disease patients, PLoS One 2013; 8: e79732.

17. Ortiz-Cabrera N.V, Gallego-Merlo J, VélezMonsalve C, de Nicolas R, Fontao Mas S, Ayuso C, Trujillo-Tiebas M.J. Nine-year experience in Gaucher disease diagnosis at the Spanish reference center Fundación Jiménez Díaz. Molecular Genetics and Metabolism Reports 1026; 9: 79-85.

18. Goker-Alpan O, Schiffmann R, LaMarca M.E, Nussbaum R.L, McInerney-Leo A, Sidransky E. Parkinsonism among Gaucher disease carriers, $J$. Med. Genet. 2004; 41: 937-940.

19. Li Y, Sekine T, Funayama M, Li L, Yoshino H, Nishioka K, Tomiyama H, Hattori N. Clinicogenetic study of GBA mutations in patients with familial Parkinson's disease, Neurobiol. Aging 2014; 35: 935 e3-8.

20. Weinreb NJ, Goldblatt J, Villalobos J, et al. Longterm clinical outcomes in type 1 Gaucher disease following 10 years of imiglucerase treatment. $J$ Inherit Metab Dis 2013; 36: 543-553.

21. McEachern KA, Fung J, Komarnitsky S, et al. A specific and potent inhibitor of glucosylceramide synthase for substrate inhibition therapy of Gaucher disease. Mol Genet Metab 2007; 91: 25967.

22. Mistry PK, Sirrs S, Chan A, et al. Pulmonary hypertension in type 1 Gaucher's disease: genetic and epigenetic determinants of phenotype and response to therapy. Mol Genet Metab 2002; 77: 91-98. 